\title{
The Development of Authentic Assessment Instruments on Anecdotal Text Material for Class X Students of SMK Yapim Indrapura, Batu Bara Regency
}

\author{
Lita Sentiana Hutapea ${ }^{1}$, Malan Lubis ${ }^{2}$, Abdurahman Adisaputera ${ }^{3}$ \\ ${ }^{1}$ Master Student in Universitas Negeri Medan, Indonesia \\ ${ }^{2,3}$ Universitas Negeri Medan, Indonesia \\ litahutapea97@gmail.com
}

\section{Abstract}

The learning process and assessment instruments provided do not cover three authentic domains in the 2013 curriculum. This study aims to describe the process of developing an authentic text assessment tool to describe the process of developing authentic assessment instruments on anecdotal text material for class $X$ students of SMK Yapim Indrapura, Batubara Regency; describe how the appropriateness of authentic assessment instruments on anecdotal text material; and describe how effective authentic assessment instruments are on anecdotal text material. This study refers to the Borg \& Gall development model. The results showed that: (1) development of authentic assessment instruments on anecdotal text material based on research and preliminary information collection, planning, initial product development, design validation and evaluation, product revisions, assessments and suggestions of language teachers and students, revisions, individual trials, revisions, small group trials, revisions, limited field trials, revisions until the product is valid and fit for use; and (2) the average percentage of all sub-components from the results of the material expert validation is $87 \%$ with "very good" criteria. The average percentage of all indicators from the results of expert evaluation validation for the multiple choice form instrument is 90.63\%; for the description instrument is $89.54 \%$; and for psychomotor instruments is $90 \%$. All evaluation expert assessments are at criteria of "very good". The teacher response results have an average total percentage $96 \%$ with "very good" criteria. The results of student responses are declared feasible and meet needs, the total percentage is average $91.6 \%$ with the overall criteria of "very good".
Keywords

instruments; authentic

assessments;

anecdotal texts

\section{Introduction}

Assessment in the 2013 curriculum must refer to authentic assessment which includes three areas of assessment, namely affective, cognitive, and psychomotor. Teachers must be creative in developing assessment instruments, Teachers are not only guided by assessment instruments provided by the government, so that learning becomes effective with quality assessment instruments. So far, the teacher's assessment of anecdotal text learning has only focused on cognitive abilities, that is, it only focuses on assessing student knowledge, without assessing students' attitudes and skills. Appropriate assessment will affect student learning processes and outcomes.

Authenthic Assessmentincludes three areas of assessment, which include attitudes, knowledge, and skills (Kunandar 2014: 159). Cognitive abilities have a major effect on 
psychomotor abilities / skills in writing anecdotal texts. Likewise with affective abilities, without students' positive affective attitudes towards the learning process, it will result in low absorption of the learning material presented. Due to neglect of affective and psychomotor abilities, students find it difficult to construct dialogues, especially dialogues that mark elements of anecdotal texts such as abstraction, orientation, crisis, reaction, and code. Students find it difficult when composing a dialogue by applying anecdotal text structure, difficulty in determining a funny story. This is evidenced from the recapitulation of learning outcomes obtained by class X students at SMK Yapim Indrapura, Batu Bara Regency TP 2019/2020 during daily tests on anecdotal text material. Only 43\% of the class $\mathrm{X}$ students completed daily tests or 13 of the 30 students, while those who did not complete reached $57 \%$ or 17 of the 30 students. Based on the speculative data, it is concluded that the process and student learning outcomes in anecdotal text material are still low. After analyzing the items used were not accurate when viewed from an authentic point of view. If students are continuously presented with appropriate assessment instruments, students will be trained to think creatively in the learning process. The final result of students will be creative in processing understanding of the material being studied, then the understanding of these students will be manifested in the form of learning outcomes expected by the teacher. Therefore, teachers must be creative in making assessment instruments in accordance with these three competencies.

The development of an authentic assessment instrument based on the 2013 curriculum on anecdotal text material is expected to be a problem solution for the problems described above. The authentic instrument book that will be developed tries to describe the concept of knowledge assessment (cognitive) and skills assessment (psychomotor). The attitude assessment will be reflected directly at the time of carrying out the knowledge assessment and skills assessment. Because in each of the two assessments applied, there are attitudinal values in the assessment activities, for example discipline and courtesy, this will be reflected when students learn and work on knowledge assessments and skills assessments provided by the teacher. That is,

Assessment is one of the factors supporting the success of the process and learning outcomes. Assessment of the learning process must be carried out in a good and correct way because it will affect the quality of learning outcomes and student graduation. Teachers as actors or implementers in the assessment must of course be professional in implementing good assessments. Teacher competence in carrying out the assessment will affect the quality of student learning outcomes in learning anecdotal texts. So far, teacher assessments have only been oriented to the aspect of student knowledge because there is no appropriate assessment book available in accordance with the 2013 curriculum. This is reinforced by research conducted by Pertiwi, Hartono, \& Syaifudin (2016: 63) which found that curriculum changes have resulted in several new text, has not been accompanied by the readiness of supporting books. Therefore, it is hoped that teacher professionalism can change student learning patterns so that the learning process and results are of higher quality by making learning products in the form of authentic assessment instrument books on anecdotal text material.

Authentic assessment has a strong relevance to the scientific approach to learning in accordance with the demands of the 2013 curriculum. This is because this kind of assessment is able to illustrate the improvement in student learning outcomes, both in the context of observing, reasoning, trying, building networks and others (Aini, 2019). 


\section{Review of Literatures}

\subsection{Authentic Assessment}

Authentic assessment can be used as a tool to measure student learning progress. Learning development means starting from the process to the end result in learning. It is the same with Cahyaningsih RD, Januariua M., and Muhammad K. (2019: 49) who state that assessment also emphasizes the assessment of process and results at the same time, so that all student activities in the learning process can be objectively assessed.

Susilo and Wardarita (2017: 186) stated, "they said the 2013 curriculum emphasizes the implementation of the authentic assessment system. Authentic assessment should be made upon the real or context which refer to students real knowledge and skill ". Supardi (2015: 24) clarifies that authentic assessment is an assessment of learning outcomes that requires students to show achievement and learning outcomes in the form of real-life abilities in the form of performance or work

Based on the description above, authentic assessment is an assessment that measures three competencies at once, namely affective (attitude), cognitive (knowledge), and psychomotor (skills) competencies in the learning process and outcomes. Authentic assessment is an effective way for teachers so that all students can achieve the final results as expected. Affective, cognitive, and psychomotor compositions are achieved through active and creative task completion by students. Authentic learning requires students to collect information with a scientific approach, understand phenomena or symptoms and relate what is learned with everyday life, both in school life and outside of school.

\subsection{Authentic Assessment Techniques}

Referring to the above opinion that authentic assessment techniques are ways that can be done to achieve effective learning processes and outcomes. In authentic assessment techniques, teachers can use various assessments tailored to the characteristics or competency demands that exist in the 2013 curriculum.Some variations of authentic assessment techniques are written assessment, oral assessment, portfolio assessment, performance assessment, project assessment, observational assessment, and selfassessment. Some of these variations are selected and adjusted to the achievement of basic competencies in learning. Authentic assessment requires teachers to assess all aspects of student learning outcomes during the learning process such as cognitive aspects, affective aspects and psychomotor aspects (Umma, 2020).

Following are the steps for developing a test instrument based on the guidebook for the development of assessment instruments (2011: 20-21) which is adapted to the Center for Development and Empowerment of Educators and Education Personnel.

\section{a. Set Test Objectives}

The first step in developing a test instrument is to set its objectives. This goal is important to set before the test is developed because what kind and how the test will be developed depends on what purpose the test is used. In terms of its objectives, there are four types of tests that are widely used in educational institutions, namely: (a) placement tests, (b) diagnostic tests, (c) formative tests, and (d) summative tests (Thorndike \& Hagen, 1977).

\section{b. Perform Curriculum Analysis}

Curriculum analysis is done by looking at and reviewing the existing curriculum in relation to the stated test objectives. This step is intended so that the test instrument 
development process always refers to the curriculum (SKKD) being used. The instrument developed should be in accordance with the indicators of achievement of a KD contained in the Standard Content (SI).

\section{c. Make a Grid}

The grid is a matrix containing the specifications of the questions (including SK-KD, material, indicators, and question forms) to be made. In creating this grid, we also have to define the form of the tests that we will give. Some of the available test forms include: multiple choice, short answer, matchmaking, true-false test, objective description, or nonobjective essay test. To make it easier to make the question grid, an example of the question lattice card is given in Learning Activity 2.

\section{d. Write Questions}

In this item writing activity, each item you write must be based on the indicators that have been written on the grid and stated in the item specifications. Item form refers to a general description and a special description that has been designed in the item specification. As for the questions in the form of description, it needs to be equipped with a more detailed scoring guideline which will be discussed in Module IV regarding the Borrowing Guidelines.

\section{e. Perform a Theoretical Instrument Analysis}

A theoretical or qualitative review of the test instrument is carried out to see the correctness of the instrument in terms of material, construction, and language. The theoretical analysis of the instrument can be done by asking for help from experts / experts, peers, or it can be done by yourself. After conducting this analysis, it can be seen whether the instrument is theoretically feasible or not. A detailed discussion regarding the study of this instrument can be read in Module VI regarding Assessment of Assessment Instruments.

\section{f. Conduct Testing and Analysis of Test Trial Results}

Before the test is used, it is necessary to conduct a test trial first. This step is necessary to obtain empirical data on the quality of the tests that have been compiled. This trial can be carried out to some students, so that from the results of this trial, the data used as a basis for analysis of reliability, validity, difficulty level, response patterns, effectiveness of distraction, differentiation, and others are obtained. If the test set that has been prepared does not meet the expected quality, based on the test results, revision of the test instrument is then performed.

\section{g. Revise the Questions}

Based on the results of the analysis of the test items, then corrections were made. Various parts of the test that still do not meet the expected quality standards need to be improved so that better test kits are obtained. For questions that are good no longer need to be addressed, but questions that are in the bad category must be discarded because they do not meet quality standards. Based on the steps for developing the test instrument described above, it is also necessary to know the principles of assessment that must be carried out. The principles of assessment put forward by the Ministry of Education and Culture (2019: 3 ) are that performance appraisal is carried out with reference to the principles: (1) is an inseparable part of the learning process; (2) reflects the problems faced in everyday life and problems in the school world; (3) using various methods and criteria in accordance 
with the characteristics and essence of the learning experience; (4) is holistic which covers all aspects of learning objectives (knowledge, skills, and attitudes).

\subsection{Und erstanding Anecdotal Text}

Anecdotal texts are synonymous with funny content in which there is an implied meaning in the form of allusions to certain characters. In connection with this, Wardani (2017: 46) states that anecdotal text is a short story, but funny and the content is in the form of satire. The satire in the text usually tells a famous character or is factual in nature.

Anecdote is a kind of short story that aims to convey interesting or strange characteristics about someone or something else (Keraf, 2010: 42). Anecdotes are one of the funny stories circulating in the community. Through anecdotes, criticism can be conveyed in language that is polite, harmless, and certainly has a funny impression. Anecdotes are short stories that are interesting because they are funny and memorable.

The characters that are told in anecdotal texts are different from the characters in the fairy tales. The characters in the anecdotes are characters who are really true, whereas in the fairy tales the characters are fictional. As stated by Chaer (2011: 158) anecdote is a funny short story about a famous character, who exists or has existed. So, the characters in the anecdote are not fictional characters, but real characters who exist in history. This suggests that humor may have existed before humans even recognized language. Almost all the time, someone tries and stimulates them to laugh with various kinds of events they have experienced.

Mahsun (2014: 23) states that anecdotal texts are a type of text that is included in the story genre, anecdotal texts have the same social goals as retelling texts. It's just that the events that are presented make participants who experience them feel annoyed or ridiculous. Many things go wrong in the community. Things like this can indirectly be conveyed in jokes, criticisms, or insinuations about what happened. It can be concluded that anecdotal texts are a means with multiple purposes, either just entertainment or indirect criticism.

Based on some of the definitions above, it can be concluded that anecdotal texts are narrative texts or funny conversations that contain an implicit meaning in the form of criticism of someone conveyed through jokes, so as not to hurt the criticized character. Narrative or conversation in anecdotal texts can be used to entertain or criticize indirectly.

\section{Research Method}

This type of research is research and development. This research method refers to the Borg \& Gall model with slight adjustments according to the research context. The authentic assessment instrument developed was in the form of an instrument book which was analyzed using a validation team of material experts and evaluation experts. The research was conducted at SMK Yapim Indrapura, North Sumatra. Subjects in this study were students of class X SMK Yapim Indrapura with 30 students, validators of authentic assessment instruments on anecdotal text material, and Indonesian language subject teachers. The object of this research is an authentic assessment instrument on anecdotal text material. The main instruments used to collect data in this assessment were questionnaires and tests. The questionnaire needed is an assessment questionnaire or responses from anecdotal text material experts, an assessment questionnaire or a response from an authentic assessment tool evaluation expert, a response questionnaire or teacher's response, and a response questionnaire or responses from students. The assessment uses a Likert scale format for the product being developed, the content of the questionnaire is in 
the form of questions related to the condition or state of the learning product being developed. The tests used are in the form of pretest and posttest which function to assess the ability of student learning outcomes before and after the teacher applies authentic assessment instrument products to anecdotal text material. The instrument must be validated first in order to obtain valid data. Test trials using validity, reliability, difficulty level, and different power as follows. The data obtained in this study are quantitative descriptive data, namely calculating the percentage of indicators for each category of the product. Analysis of the validity of the authentic assessment tool book from material experts and evaluation experts was analyzed using the formula from Sugiyono. This formula is used to calculate the percentage of the validation questionnaire.

$$
P=\frac{f}{N} \times 100 \quad \text { (Sugiyono, 2013: 141) }
$$

Information:

P: Percentage of scores

f: total score obtained

$\mathrm{N}$ : the maximum number of scores

The results of calculations using the formula above are generated numbers in the form of a percent. The classification of the score is then converted into a classification in the form of a percentage, then interpreted with a qualitative sentence.

\section{Discussion}

\subsection{The Process of Developing Authentic Assessment Instruments on Anecdotal Text Material}

According to Sinaga (2020) The curriculum is a tool to achieve educational goals without an appropriate and appropriate curriculum it will be difficult to achieve the desired educational goals and objectives as an important tool to achieve goals. The process of developing an authentic assessment instrument on anecdotal text material is carried out in several stages, namely preliminary studies, initial product development, and product testing.

\section{a. Phase I Preliminary Study}

The first stage carried out is a preliminary study. A preliminary study was carried out to understand the idea that the product developed was in accordance with the needs in the field. The needs analysis in this development research begins by distributing a needs analysis questionnaire to 30 class $\mathrm{X}$ students and Indonesian language teachers at SMK Yapim Indrapura Batubara Regency to authentic assessment instruments on anecdotal text material.The results of the analysis from the questionnaire aim that the resulting learning products can help the learning process run more effectively.

Analysis resultsshows that the Indonesian language teacher at SMK Yapim Indrapura, Batubara Regency (100\%) stated that they were familiar with the authentic assessment instrument on the developed anecdotal text material, while 27 people or $90 \%$ of the total students stated that they were not familiar with the authentic assessment instrument on the anecdotal text material developed. Teachers and students (100\%) stated that they have never used authentic assessment instruments on anecdotal text material in the learning process. The teacher (100\%) stated that they needed an authentic assessment instrument on the developed anecdotal text material and $87 \%$ of students stated that they needed an authentic assessment instrument on the anecdotal text material developed in the learning process. The product developed for the teacher's handbook when teaching anecdotal text material in class X SMK. 


\subsection{Phase II Initial Product Development}

Initial product development was carried out by designing an authentic assessment instrument on anecdotal text material. This is done with the aim of indicating the direction of the product making before the validation stage. Making a cover design, foreword; table of contents; KD grouping, and indicators with assessment aspects; explanation of the meaning of knowledge assessment; instrument grille; multiple choice instruments and essays; answer keys and scoring guidelines ;. Chapter discuss skills assessment; performance, project and portfolio appraisal instruments; Skills assessment rubric; and scoring guidelines and answer keys.

\subsection{Product Trial Stage}

Authentic assessment instrument products on anecdotal text material developed through three stages of testing, namely individual trials (3 students); small group trial ( 9 students); and limited field trials (30 students). The trials carried out are not tests of the whole product or authentic assessment instruments on anecdotal text material that has been developed. The product developed is for teacher assessment guidelines, while for students it is an authentic question instrument that is in the product being developed. Therefore, only authentic question instruments were tested for students, not the whole product of authentic assessment instruments on anecdotal text material. Individual trials obtained an average value $75.87 \%$ with "good" criteria. Small group trials obtained an average value $79.85 \%$ with "good" criteria. Furthermore, limited field trials obtained an average value $91.6 \%$ with "very good" criteria.

The product is tested for feasibility before being tested in the field. The product is suitable for use after the validator validates the product and states that the product is suitable for use as a learning product in the field. After all the stages of developing an authentic assessment instrument on anecdotal text material are completed. Then the authentic assessment instrument on anecdotal text material is ready for use by grade $\mathrm{X}$ students of SMK Yapim Indrapura, Batubara Regency.

\subsection{Feasibility of Authentic Assessment Instruments on Anecdotal Text Material}

The appropriateness of authentic assessment instruments on anecdotal text material is obtained from the results of validation and assessment provided by material experts and evaluation experts. Each material expert and evaluation expert consists of 2 validators. The total number of validators is four people. The criteria for each assessment indicator as a whole are determined by the average score of each expert's assessment criteria. The results of the assessment were analyzed to determine whether or not an authentic assessment instrument was appropriate for anecdotal text material to be tested in class X SMK Yapim Indrapura, Batubara Regency. Whether or not an authentic assessment instrument is appropriate for anecdotal text material that has been developed in the product is tried out for the tenth grade students of SMK Yapim Indrapura, Batubara Regency. After that, the product is given to the teacher to find out the results of the assessment and the suggestions given. The final stage, tested the authentic assessment instrument on the anecdotal text material that had been developed. The trial was carried out with the individual trial stage to 3 students; small group trials with 9 students; and limited field group trials to 30 students of class X SMK Yapim Indrapura. 


\subsection{Presentation of Data Validation Results by Material Experts}

The authentic assessment instrument material expert on anecdotal text material corrects each assessment indicator that has been prepared in the assessment questionnaire. The validation of the assessment instrument material was carried out by prof. Amrin Saragih, MAPh.D., and Mara Untung Ritonga. M.Hum., Ph.D. who is a lecturer at the State University of Medan. Material assessmentauthentic assessment instruments This is done to improve the quality of the material contained in the product authentic assessment instruments that was developed. Validation processauthentic assessment instruments by material experts through several stages of validation. Product validation is carried out until it meets the criteria of validity / fit for use in the field according to expert validators.

\section{a. Data Validation Results by Material Experts I}

The results of the material expert validation on the sub-component of the assessment technique for the presentation of the assessment instrument obtained an average percentage of $93 \%$ with the criteria "very good", the language and written instrument sub-components obtained an average percentage of $92 \%$ with the criteria "very good", the instrument activity sub-component the assessment obtained an average percentage of $88 \%$ with the criteria "very good", the sub-component of the completeness of the assessment instrument obtained an average percentage of $100 \%$ with the criteria "very good". The average percentage of all the material assessment sub-components is $93 \%$ with the criteria "very good". Therefore, the authentic assessment instrument on the developed anecdotal text material deserves to be tested in the field without any revisions from material expert validators and can meet the demands of learning needs.

\section{b. Data Validation Results by Material Experts II}

The results of the material expert validation on the sub-component of the assessment of the assessment instrument presentation technique obtained the average percentage $89 \%$ with "very good" criteria, the language and writing sub-components of the instrument obtained the average percentage $75 \%$ with "good" criteria, the sub-component of the assessment instrument activity obtained an average percentage $75 \%$ with "good" criteria, the sub-component of the completeness of the assessment instrument obtained an average percentage $88 \%$ with "very good" criteria. The average percentage of all sub-components of material assessment is $82 \%$ with the criteria "very good".

\section{c. Data Validation Results by Material Experts I and II}

The results of the validation of material experts I and II on the sub-component of the assessment of the assessment instrument presentation technique obtained the average percentage $91 \%$ with "very good" criteria, the language and writing sub-components of the instrument obtained the average percentage $83.33 \%$ with "very good" criteria, the subcomponent of the assessment instrument activity obtained an average percentage $81.25 \%$ with "very good" criteria, the sub-component of the completeness of the assessment instrument obtained an average percentage $93.75 \%$ with "very good" criteria. The average percentage of all sub-components of the material assessment is $87 \%$ with "very good" criteria. Therefore, the authentic assessment instrument on the developed anecdotal text material deserves to be tested in the field and can meet the demands of learning needs. 


\subsection{Presentation of Data Validation Results by Evaluation Experts}

The evaluation expert validates the authentic assessment instrument on the anecdotal text material that has been developed. The evaluation expert to validate the assessment instrument is Prof. Dr. Efendi Napitupulu, M.Pd., and Dr. Zulkifli Matondang, M.Si. who is a lecturer at the State University of Medan. Validationauthentic assessment instruments on anecdotal text material this is done to improve the quality of the material and instruments inside product that was developed. The aspects assessed were the multiple choice test instruments, descriptions, and psychomotor test instruments. Validation processassessment instrument by evaluation experts through several stages of validation. Product validation is carried out until it meets the criteria of validity according to the validator.

\subsection{Data Validation Results by Evaluation Experts I and II}

\section{a. Multiple Choice Test Instrument Item Assessment}

The results of the validation of evaluation experts I and II on the material domain indicator have an average percentage $90.63 \%$ with "very good" criteria, the construction sector indicator has an average percentage $87.50 \%$ with "very good" criteria, the language domain indicator has an average percentage $90 \%$ with "very good" criteria. The number of the average percentage of all indicators from the results of the validation of evaluation experts I and II is $90.63 \%$ with "very good" criteria. This means that the authentic assessment instrument on the developed anecdotal text material deserves to be tested in the field and can meet the demands of learning needs.

\section{b. Assessment of Test Instruments Items in Description Form}

The results of the validation of evaluation experts I and II on the material domain indicator have an average percentage $90.63 \%$ with the criteria of "very good", the indicator in the field of construction has an average percentage of $88 \%$ with the criteria "very good", the indicator in the domain of language has an average percentage of $90 \%$ with the criteria "very good". The number of the average percentage of all indicators from the results of the validation of evaluation experts I and II is $89.54 \%$ with "very good" criteria. This means that the authentic assessment instrument on the developed anecdotal text material deserves to be tested in the field and can meet the demands of learning needs.

\section{c. Instrument Item Assessment for Psychomotor}

The results of the validation of evaluation experts I and II on the material domain indicator have an average percentage of $91 \%$ with "very good" criteria, construction sector indicators have an average percentage of $78 \%$ with "good" criteria, language domain indicators have an average percentage of $90 \%$ with "very good" criteria. The average percentage of all indicators from the validation results of the evaluation I and II experts is $90 \%$ with the criteria "very good". This means that the authentic assessment instrument on the developed anecdotal text material deserves to be tested in the field and can meet the demands of learning needs.

\subsection{Results of the Assessment of Indonesian Language Teachers on the Assessment instrument}

The assessment of Indonesian language teachers on authentic assessment instruments on anecdotal text material was carried out by Lita Sentiana Hutapea, S.Pd., an Indonesian language subject teacher in class X of SMK Yapim Indrapura, Batu Bara Regency. The results of the assessment are in the form of scores on learning indicators that are in 
accordance with Indonesian language learning, especially on anecdotal text material and instruments used in authentic anecdotal text assessments. The results of the response or responses made by the Indonesian language teacher concluded that the authentic assessment instrument on anecdotal text material was included in the "very good" criteria with a total average percentage of $96 \%$ with the criteria "very good". The results of the response from Indonesian language teachers to authentic assessment instruments on anecdotal text material in detail can be seen in the appendix. Based on the results of the assessment of authentic assessment instruments on anecdotal text material by the teacher, it is concluded that the learning products developed can meet the demands of learning needs to be taught to class X students of SMK Yapim Indrapura, Batu Bara Regency.

\subsection{Testing of Authentic Assessment Instruments}

The stage of conducting trials on authentic assessment instruments on anecdotal text material through 3 trial processes, namely: (1) individual trials, (2) small group trials, and (3) limited field trials. The authentic assessment instrument on the anecdotal text material developed is a product for the teacher, while its application is to students. Therefore, what was tested on students was the existing test instruments in authentic assessment instruments on anecdotal text material, not the entire learning product developed. The results of the trials carried out can be described as follows.

\section{a. Student Testing Results on Authentic Assessment Instruments in Individual Testing}

The result of the average percentage of the assessment of the material assessment indicators has an average percentage $73.61 \%$, an indicator of language grading with averages $79 \%$, and the average attractiveness assessment indicator $75 \%$. The average percentage yield of all individual trials is $75.87 \%$ with "good" criteria. The trial results show that the instrument is good enough for learning, but there are still weaknesses after doing individual trials. These weaknesses are: (1) some of the words written on the instrument are imperfect; and (2) several sentences of convoluted question instruments.

\section{b. Student Testing Results on Authentic Assessment Instruments in Small Group Trials}

The result of the average percentage of the assessment of the material assessment indicators has an average percentage $79.17 \%$, an indicator of language grading with averages $76.39 \%$, and the average attractiveness assessment indicator $84 \%$. The average percentage yield of all individual trials is $79.85 \%$ with "good" criteria. This means that the test instruments in the products that have been developed are in accordance with the needs of students.

\section{c. Student Testing Results on Authentic Assessment Instruments in Limited Field Trials}

The average percentage result shows that the assessment of the material assessment indicators has an average percentage $90.85 \%$, an indicator of language grading with averages $92 \%$, and the average attractiveness rating indicator $91.9 \%$. The mean percentage results of all limited field tests are $91.6 \%$ with "very good" criteria. The results of the response of the tenth grade students of SMK Yapim Indrapura, Batu Bara Regency, it was concluded that the authentic assessment instrument on the anecdotal text material that had been developed was declared feasible and met the needs with the overall criteria "very good". 


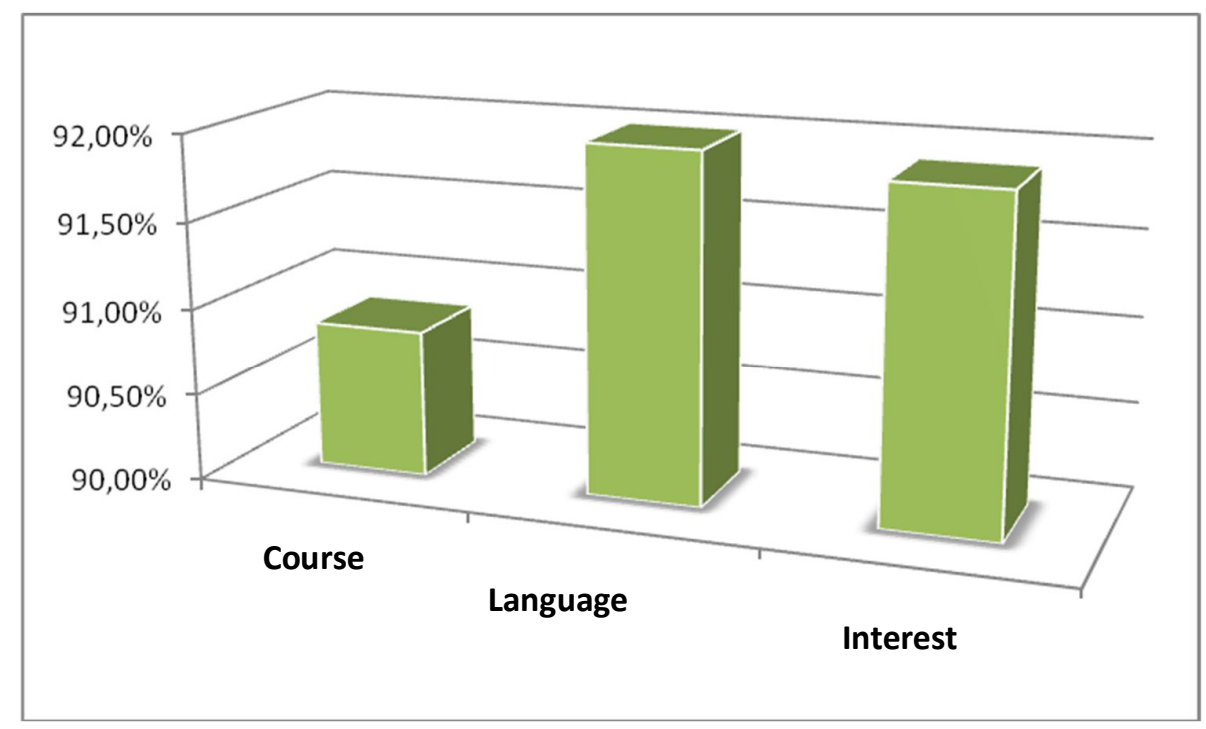

Figure 1. Assessment of Grade X Students of SMK Yapim Indrapura

\section{Conclusion}

Based on the formulation, objectives, results, and discussion of research on the development of authentic assessment instruments on anecdotal text material for class $\mathrm{X}$ students of SMK Yapim Indrapura, Batubara Regency, described earlier, it can be concluded as follows:

1. The process of developing an authentic assessment instrument on anecdotal text material for grade X students of SMK Yapim Indrapura, Batubara Regency, is carried out in several stages, namely:

a. The first stage carried out is a preliminary study. One of them is doing needs analysis. The needs analysis in this development research begins by distributing a needs analysis questionnaire to 30 grade $\mathrm{X}$ students and Indonesian language teachers at SMK Yapim Indrapura, Batubara Regency. The results of the needs analysis are based on the table above, it is known that the Indonesian language teacher at SMK Yapim Indrapura, Batubara Regency (100\%) stated that they were familiar with authentic assessment instruments on the developed anecdotal text material, while 27 people or $90 \%$ of the total students stated that they were not familiar with the assessment instrument. authentic on the developed anecdotal text material. Teachers and students $(100 \%)$ stated that they have never used authentic assessment instruments on anecdotal text material in the learning process.

b. Initial product development was carried out by designing an authentic assessment instrument on anecdotal text material. Prepare cover design, preface; table of contents; KD grouping, and indicators with assessment aspects; explanation of the meaning of knowledge assessment; instrument grille; multiple choice instruments and essays; answer keys and scoring guidelines ;. Chapter discusses skills assessment; performance, project and portfolio appraisal instruments; Skills assessment rubric; and scoring guidelines and answer keys. The final part of the assessment instrument is a list of references used in the product being developed.

c. product validation by material and evaluation expert validators, product revisions, assessments and suggestions of language teachers and students, revisions, individual 
trials, revisions, small group trials, revisions, limited field trials, revisions until the product is valid and suitable for learning.

2. Eligibility Authentic assessment instrument on anecdotal text material for grade $X$ students of SMK Yapim Indrapura, Batubara Regency meets the requirements and is suitable for use for learning on anecdotal text material. Based on the evaluation of material experts, evaluation experts, Indonesian language teacher assessments, and student responses. The average percentage of all sub-components from the validation results of material experts I and II is $87 \%$ with "very good" criteria. The average percentage of all indicators from the results of validation by evaluation experts I and II for the multiple choice form instrument is $90.63 \%$ with "very good" criteria. The average percentage of all indicators from the results of validation by evaluation experts I and II for the instrument description is $89.54 \%$ with "very good" criteria. The average percentage of all indicators from the results of expert validation evaluation I and II for psychomotor instruments is $90 \%$ with the criteria "very good". The results of the teacher's response to the assessment instrument have an average total percentage of $96 \%$ with the criteria "very good". The results of the responses of grade X students of SMK Yapim Indrapura, Batubara Regency to authentic assessment instruments on anecdotal text material that has been developed is declared feasible and meets the average percentage requirement $91.6 \%$ with "very good" criteria.

\section{References}

Aini, S., Ssetiawan, D., and Siman. (2019). Evaluation of Authentic Assessment Implementation in Public Elementary School 101775 Sampali, Deli Serdang Regency Academic Year 2019/2020. Budapest International Research and Critics in Linguistics and Education (BirLE) Journal Vol 2 (4).

Cahyaningsih, R.D., Januariua. M., and Muhammad K. (2019). Penilaian Autentik Keterampilan Membaca Berbasis Strategi Metakognitif. Jurnal Kredo, 3 (1): 47-55.

Chaer, A. (2011). Cekakak Cekikik. Jakarta: Rineke Cipta.

Kemendikbud. (2017). Bahasa Indonesia SMA/MA/SMK/MAK Kelas X Edisi Revisi 2017. Jakarta: Kementerian Pendidikan dan Kebudayaan.

Keraf, G. (2010). Argumentasi dan Narasi. Jakarta: Gramedia

Kunandar. (2014). Penilaian Autentik (Penilaian Hasil Belajar Peserta Didik Berdasarkan Kurikulum 2013). Jakarta: Rajawali Pers.

Mahsun. (2014). Teks dalam Pembelajaran Bahasa Indonesia Kurikulum 2013. Jakarta: PT Raja Grafindo Persada.

Pertiwi, D.O., Hartono, B., \& Syaifudin, A. (2016). Pengembangan Buku Pengayaan Menyusun Teks Eksposisi Berbasis Kearifan Lokal Bagi Siswa Sekolah Menengah Pertama (SMP). Jurnal Pendidikan Bahasa dan Sastra Indonesia, 5 (2): 62-69.

Rusman. (2017). Pembelajaran Tematik Terpadu: Teori, Praktik dan Penilaian. Jakarta: Raja Grafindo Persada.

Sani, R.A. (2016). Penilaian Autentik. Jakarta: Bumi Aksara.

Sinaga, A.I., Salamuddin, Khairini, D. (2020). Patterns of Islamic Education Learning in Applying 2013 Curriculum in SMPN 27 Medan. Budapest International Research and Critics in Linguistics and Education (BirLE) Journal Vol 3 (3): 1551-1557.

Sugiyono. (2013). Metode Penelitian Pendidikan: Pendekatan Kuantitatif, Kualitatif, dan $R \& D$. Bandung: Alfabeta.

Supardi. (2015). Penilaian Autentik. Jakarta: Raja Grafindo. 
Susilo, P., and Wardarita, R. (2017). Developing Assessment Instrument on Short Story Appreciation and Production for Senior High School Students. Journal of Education, Teaching and Learning, 2 (2): 186-191.

Thorndike,E.L and H.P. Hagen. (1977). Measurement and Evaluation in Psychology and Education. New York: Jhon Wiley.

Umma, R.J., Adisaputera, A., and Pramuniati, I. (2020). Development of Text Review Assessment Model Using Authentic Assessment in 11th Grade Students of Senior High School Negeri 1 Dolok Batunanggar, Simalungun Regency. Budapest International Research and Critics in Linguistics and Education (BirLE) Journal Vol 3 (2): 1099-1112.

Wardani, et al. (2017). Studi Kasus Pembelajaran Menulis Teks Anekdot padaKurikulum 2013 di SMA Negeri 1 Surakarta. Aksara, 2 (1). 